he suggests that it is probable that three broods are reared when nesting begins early in April and only two when nesting is delayed by weather until May; the period between rearing one brood and commencing another averages ten days, making altogether 113 days or an average of four months devoted to the rearing of their young. There is confirmation of the observations of B. H. Ryves (Brit. Birds, August 1943), including retardation of egg-laying due to inclement weather. After the destruction of previous clutches the rapidity of egg-laying produced fresh eggs after intervals of only four or five days. An average of five young per pair is a normal seasonal increase. There are also interesting observations on the building of domed nests inside nest-boxes.

\section{Powdery Mildew of the Rose}

Horticultural beauty of the rose often depends as much on the foliage as upon the flowers. Powdery mildew caused by the fungus Spaerotheca pannosa is a very widespread trouble upon the leaves, particularly when roses are grown under glass. The disease can be minimized, but not controlled, by keeping temperature and humidity as low as possible for the growth of the plants. Mr. Wilbur D. McCellan has re-investigated the problem of control, chiefly by spraying methods (Cornell University Agricultural Experimental Station, Bull. 785. Ithaca, N.Y.; June 1942). Sulphur-containing sprays were found to be generally superior to those containing copper, though malachite green gave the best eradicant control. Good control without injury to foliage resulted from the use of particulate sulphur. Various wetting agents were also studied, and useful control was obtained by vaporizing sulphur at $112-115^{\circ} \mathrm{C}$. A considerable reduction in the amount of mildew can be obtained by frequent syringing. The paper also includes descriptions of a method of measuring contact angles of spray drops, as a means of comparing their wetting power.

\section{Mammalian Reproduction}

THE title of a recent publication (1943) of the Imperial Bureau of Animal Breeding and Genetics fully indicates its contents. It is "Gestation Periods, a Table and Bibliography", compiled by J. H. Kenneth (Pp. 23. Edinburgh and London : Oliver and Boyd, 1943. 2s.). It contains a very long list of mammals with their common and scientific names, followed by the time in days of their gestation periods. The average time is given and also the rinimum and maximum times where available. Where different times are given by different authorities, these are cited separately and all data are followed by references to the publications from which they are taken. In domestic mammals, separate times are given for the different breeds and in some instances for crosses between them. A number of workers will be grateful for this ready access to a scattered literature. A wide range of variation is shown from the sixteen days of the golden hamster, Mesocricetus auratus, up to the 426 days of the okapi, Okapi johnstoni, and 641 days of the elephant, Elephas indicus.

\section{Health of Iceland}

According to the Medical Officer of November 13, the population of Iceland is now 121,579, of which 38,300 live in the capital, Reykjavik. The marriagerate is $6 \cdot 6$, the death-rate 9.9 and infant mortality
35.9 per 1,000 live births. The chief causes of death are old age (1.6 per 1,000), closely followed by diseases of the heart and cancer, which both reach 1.3 per 1,000. Apoplexy, tuberculosis, pneumonia and accidents all rank about the same $(0 \cdot 8-0.9$ per 1,000$)$. Apart from influenza and pneumonia, infectious diseases are not important causes of death. Scarlet fever and erysipelas are of a much more virulent form than in Great Britain. 229 cases of tuberculosis were notified, of which 60 were non-pulmonary, and 104 cases were fatal. School medical inspection of children especially as regards tuberculosis is compulsory. Venereal disease is notifiable, and there has not been a diminution of cases during the last ten years. Occupation by foreign troops has been followed by more employment, more money, higher prices, longer working hours, housing difficulties, more accidents in factories and on roads and increase in immorality.

\section{Typhus Fever in Bolivia}

According to the delegate of Bolivia at the eleventh Panamerican Sanitary Congress at Rio de Janeiro during September 7-15, 1942 (Bol. Of. San. Panamer., 22, 590; 1943), typhus fever, which was formerly confused with typhoid fever, is an endemic disease which causes serious epidemics in Bolivia in the winter months. Its centre is the high Andean Plateau which has a million inhabitants, 90 per cent of whom are natives. The largest city affected is La Paz, which is in direct contact with the Indian population of the highlands as a trading, commercial and supply centre. The disease occurs only sporadically in the valleys, although they are inhabited by the same kind of natives as those on the plateau. During the Chaco campaign, when thousands of plateau natives were fighting among the rest of the inhabitants under lice-infested insanitary conditions, not a single case of epidemic typhus occurred, although in 1933 and 1935 the plateau was suffering from a great epidemic. During the last two years, cases of typhus have been uncommon and have been replaced by relapsing fever. The probable explanation of this is that the virus of the disease (Rickettsia prouazeki) is of a special type adapted to the Bolivian plateau and unable to flourish in a warmer climate, or that the lice in the valleys for some unknown reason do not transmit the disease.

\section{Cerebrospinal Meningitis in War-time}

According to the July issue of the Statistical Bulletin, the organ of the Metropolitan Life Insurance Company of New York, cerebrospinal meningitis recorded its most extensive outbreak in the history of the United States in 1943 : the number of cases up to the end of July was more than 13,000, and the total for the year will probably exceed 17,000 cases. Practically every part of the United States has been attacked, the State most affected being Rhode Island. Earlier, the disease was at an extremely low ebb, but in 1942 new cases began to increase in number. A large proportion of the cases reported in 1943 occurred in Army camps. England has probably suffered from cerebrospinal fever more than any other belligerent in this War, especially during 1940 and 1941, when the number of cases was nearly ten times the average for the three previous years. As the result, however, of the introduction of sulpha drugs in 1943, the majority of cases are now cured and the treatment of the disease has been revolu- 
tionized. In the American Army camps, the death. rate has been only $3 \frac{1}{2}$ per cent as compared with 34 per cent in the War of 1914-18; relapses have been virtually eliminated and the frequency of complications has been greatly reduced.

\section{Training in Special Librarianship}

THE very great increase in information services has created a demand for special librarians and informa. tion officers far in advance of the available supply of trained librarians. The Association of Special Libraries and Information Bureaux is therefore continuing to organize its emergency training in the technique of the special library by means of courses of twelve lectures given at weekly intervals, the first of which will start on February 16. Naturally such courses cannot pretend to give a complete training in librarianship; they are intended as first-aid help for inexperienced assistants in special libraries or information bureaux in place of the more thorough training not obtainable through war conditions. In the light of the experience gained in 1943, modifications have been made in the syllabus, which can be obtained on application to the General Secretary, ASLIB, 31 Museum Street, London, W.C.1. A fee of five guineas per student is charged for the course.

\section{Clough Memorial Research Fund}

THIs fund was instituted in 1935 for the purpose of encouraging geological research in Scotland and the north of England, the latter defined as comprising the counties of Northumberland, Cumberland, Durham, Westmorland and Yorkshire. A sum of approximately $£ 30$ is available annually. Applications for grants for the period April 1, 1944, to March 1945 are invited. Applications should state the nature of research to be undertaken, the amount of grant desired and the specific purpose for which it will be used, and whether any other grant-in-aid has been obtained or applied for. Applications must be in the hands of the Secretary, Clough Research Fund Committee, Edinburgh Geological Society, Synod Hall, Edinburgh, not later than March 1, 1944.

\section{Recent Earthquakes}

DuRrva September 1943, ten strong earthquakes were registered at the Dominion Observatory, Wellington, New Zealand. Epicentres have been determined at the Observatory as follow : September 6, near Macquarie Island; September 14, (1) near New Caledonia; (2) Samoa region; (3) region of $26^{\circ}$ S., $175^{\circ}$ W.; September 17 , near Solomon Islands ; and September 27, in the Kermedecs region. Sixteen other earthquakes and tremors were felt in New Zealand during the month. The strongest of these was Scale IV on the Modified Mercalli scale, and shocks with this intensity occurred on (1) September 3 , in parts of Canterbury and Westland ; (2) Septernber 12 in Otira and near Arthur's Pass ; and (3) Sep. tember 28 at Eketahuna. Seismographs at Toledo in Spain registered twenty-two strong earthquakes during September 1943, the shocks of September 6, 10 and 14 being described as violent.

During the period Sept. 11-Nov. 26 inclusive, twenty strong earthquakes were registered at Kew Observatory. By far the largest ground vibration amplitudes at Kew were on Nov. 26, $1120 \mu$; Nov. 6, $590 \mu$; Oct. 23, 340 $\mu$; and Nov. 3, $330 \mu$. The shock of Nov. 26 was in Turkey and has already been reported in NATuRE (Dec. 11, p. 684). The shock of Nov. 6 was probably the one with epicentre just west of the island of Aroe Eilanden in the Banda Sea (lat. $5 \cdot 5^{\circ}$ S., long. $134^{\circ}$ E.). The earthquake of October 23 probably had its epicentre 30 miles eastnorth-east of Sylhet in Assam, while that of November 3 probably originated 30 miles north-west of Susitna in Alaska. The last three mentioned epicentres were determined provisionally by the United States Coast and Geodetic Survey in co-operation with Science Service and the Jesuit Seismological Association on instrumental evidence. The next largest amplitudes during the period at Kew were Nov. 24, $105 \mu$; Oct. 24, $32 \mu$; Sept. 24, $28 \mu$; Oct. $22,25 \mu$; Oct. $16,21 \mu$; and Oct. $21,17 \mu$. The last-named had its epicentre determined by the U.S. Coast and Geodetic Survey as being near lat. $16.5^{\circ}$ S., long. $178^{\circ}$ E., which is in the Pacific Ocean due north of the island of Vita Levu and due west of the island of Vanua Levu, both of the Fiji Islands group.

\section{Announcements}

The Council of the Institute of Metals has elected four honorary members of the Institute, one each from the four principal Allied Nations : Her Excellency Madame Chiang Kai-Shek (China); Sir Lawrence Bragg (Great Britain); Dr. Irving Langmuir (United States of America); Prof. P. Kapitza (Union of Soviet Socialist Republics).

The Astronomer Royal, Sir Harold Spencer Jones, will deliver the 1944 May Lecture of the Institute of Metals. He has chosen as his subject "Metals in the Stars".

THE Council of Newnham College, Cambridge, has awarded a Muriel Wheldale Onslow Prize for outstanding work in biology to Dr. A. B. Beakbane, of the East Malling Research Station.

Prof. J. McLean Thompson will read a paper entitled "Towards a Physiological Interpretation of Modern Flowering", before the Linnean Society on February 10 , at 2.30 p.m.

Dr. Paux Herget, formerly assistant professor of astronomy at the University of Cincinnati, has been appointed director of Cincinnati Observatory in succession to the late Dr. Elliott Smith, and has been made professor and head of the Department of Astronomy in the University of Cincinnati. Dr. Herget, who is thirty-five years old, is an authority on celestial mechanics, having specialized on the computation of the orbits of minor planets and comets.

AT the annual meeting of the New York Academy of Sciences held on December 15, the following were elected to honorary life membership: Dr. O. T. Avery, of the Rockefeller Institute for Medical Research, New York ; Prof. Alexander Fleming, professor of bacteriology, University of London (St. Mary's Hospital Medical School); Sir Frederick Gowland Hopkins, recently Sir William Dunn professor of biochemistry in the University of Cambridge; Dr. Alfred L. Kroeber, director of the Museum of Anthropology, University of California; Prof. The Svedberg, head of Physical Chemistry Institute, University of Uppsala; Prof. Arne Tiselius, professor of biochemistry, University of Uppsala. 